\title{
An Empirical Analysis of the Relationship between Foreign Trade and Carbon Emissions of China's High Tech Industries
}

\author{
Hang MI \\ Department of Economics and Management \\ North China Electric Power University \\ Baoding, 071003, China \\ amigege@live.com
}

\begin{abstract}
With the continuous development of trade and economy, China's high technology industry has a significant characteristics of "the imbalance of environment and interests", the increase of carbon emissions has a huge obstacle to the sustainable development of trade economy. This paper selects the volume of China's high technology industry foreign trade import and export and carbon emissions as basic data during 1994-2013 to and analyze. The results showed that their relation is the height of the long-term positive correlation and significant short-term dynamic relationship, along with the import and export volume of high technology industries in China foreign trade growing, carbon emissions is also showing the similar growth tendency. The results of the empirical analysis show that the development of foreign trade in China's high-tech industry will affect China's environmental problems, carbon emissions will still face a long-term severe challenge.
\end{abstract}

Keywords-High technology industry; foreign trade; carbon emission

\section{INTRODUCTION}

With the deep of economic globalization, China's trade economy has entered a stage of rapid development. As a strategic leading industry of the national economy, the high-tech industry has greatly affected the adjustment of industrial structure and the change of the mode of economic development.[1] It has become the core of the competition of the comprehensive national power in the world. High-tech industry is intensive of the talent, knowledge, technology and the capital, and embodies the advanced technology industries, including pharmaceutical manufacturing, aerospace manufacturing, electronic and communication and equipment manufacturing, electronic computer and office equipment manufacturing, medical equipment and instrument manufacturing, which is the strategic pillar industry to promote China's industrial upgrading and drive economic growth.

In recent years, the emission of pollutants has been on the upward trend in China. As an important indicator of the pollution degree in a country, "carbon emission" is one of the most important tools to reflect the severity of environmental pollution.[2] With the increase of carbon emissions, the damage to the ecological environment will become more and more obvious, and for the sustainable development of the trade economy, it also will cause great obstacles Therefore, it has particularly important practical significance to the sustainable development of ecological trade and the healthy and stable development of high technology industry that analyze the relations of carbon emissions and high technology industries in our country foreign trade.

\section{CARBON DIOXIDE EMISSIONS ESTIMATION}

As there is no the corresponding statistics of carbon emissions in the China statistical yearbook, it is necessary to calculate the carbon emissions of our country according to the formula over the years. The source of carbon emissions is mainly fossil fuel energy and it mainly includes coal, oil and natural gas three categories, so for the calculation of carbon emissions, the most of scholars multiply the consumption of various energy sources and carbon emissions coefficient of all kinds of energy, then add total sum.[3] This paper will estimate the industrial carbon dioxide emissions by the carbon dioxide emission coefficient published by IPCC in 2006 and the average low heating coefficient of standard coal in various energy sources of our country. Formula defined as:

$$
C Q=\left[(\eta \times A)_{i} \times E_{i}\right]
$$

Among them, CQ indicates that the industrial carbon dioxide emissions, nand $\mathrm{A}$ are $\mathrm{CO}_{2}$ emission coefficient of various energy and average low calorific value, i represents energy types, so $(\eta \times A)_{i}$ represents the carbon dioxide volume of unit $\mathrm{i}$ energy, and $E_{i}$ represents industry $\mathrm{i}$ energy consumption.[4]

Because the high technology industry includes the pharmaceutical manufacturing, aerospace manufacturing, electronics and communications equipment manufacturing, medical equipment and instrument manufacturing industry 5 categories, this paper will use the formula(1) to count in a separate way of the industry and calculate the total sum finally. 
III. ANALYSIS OF THE RELATIONSHIP BETWEEN FOREIGN TRADE AND CARBON EMISSIONS OF CHINA'S HigH TECH INDUSTRIES

\section{A. Data analysis}

Through the calculation of our country's carbon emissions in 1999-2013 years and the import and export volume of foreign trade in high-tech industries, we draw a corresponding tendency chart, as shown in Fig. 1. In 20 years, the import and export volume of China's high-tech industry has increased several times. At the same time, it can be seen from Fig. 1 that compared to the import and export trade volume growth trend, the growth trend of China's carbon emission and high technology industry trade are similar basically, which indicates that there is a linear relationship between the carbon emissions of China and foreign trade of high-tech industries.

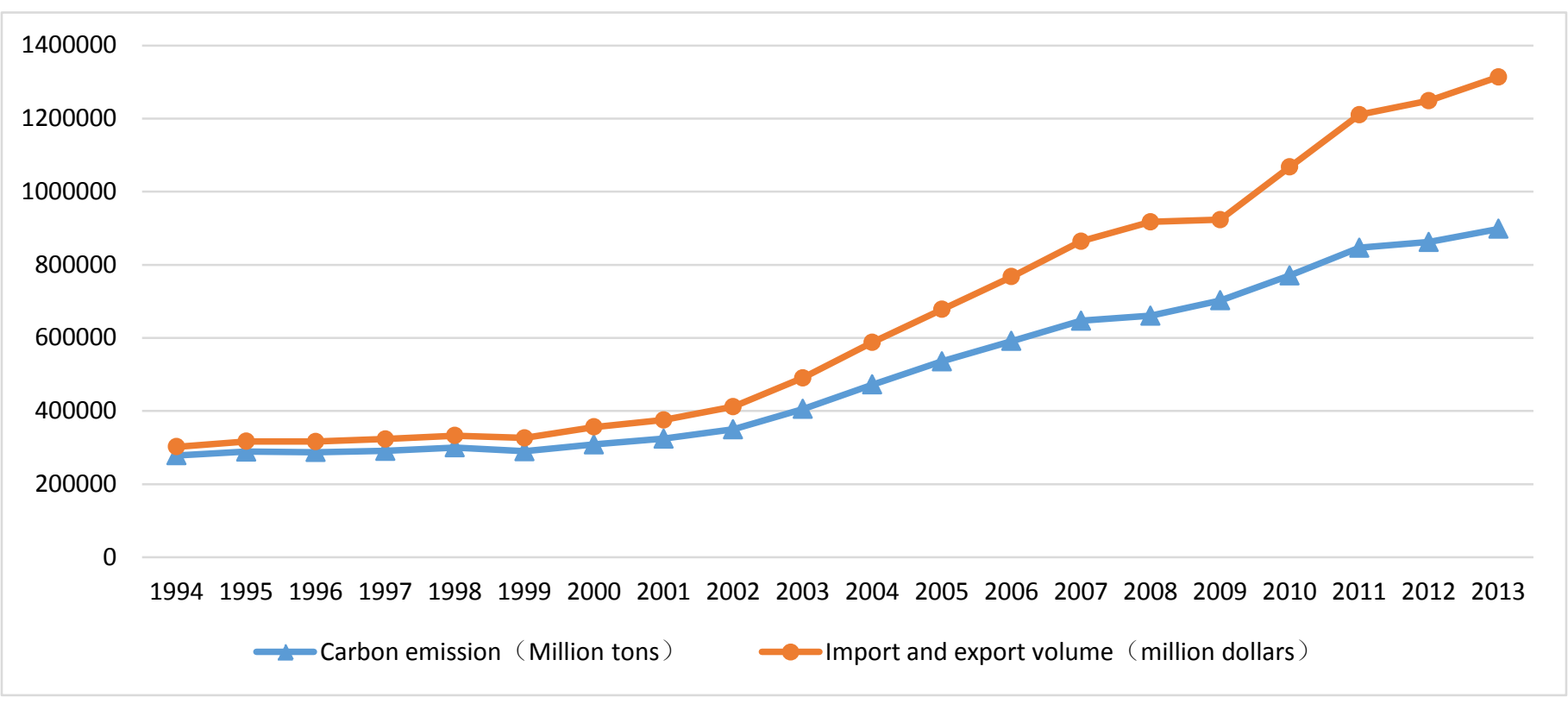

Fig.1. The trend of the import and export volume and carbon emissions of China's high tech industries

\section{B. Correlation analysis}

Based on Eviews6.0, calculating the China's carbon emission $\mathrm{C}$ and the time series data of high technology industry import and export volume $\mathrm{X}$, we got the linear equation :

$\mathrm{LNC}=0.359813 \mathrm{LNX}+8.487564$ and the correlation coefficient $\mathrm{R}$ was 0.9924 and the statistic $\mathrm{F}$ was 1363 . Besides, the probability value of $p=0.01$, it is less than the significance level $\alpha=0.05$ corresponding to the statistic $F$, so the original hypothesis $\mathrm{H}_{0}$ is rejected It indicated that there was a high positive correlation between the foreign trade of China's high-tech industries and carbon emission.

Though it is calculated that the carbon emissions and high technology industries in China's import and export trade volume have a significant relationship according to the Eviews6.0, it may also appear the phenomenon of spurious regression from the table indicating the change of trend growth. In order to avoid spurious regression between the carbon emissions and foreign trade volume of China's high-tech industry, it is necessary to inspect and analyze.

\section{EMPIRICAL ANALYSIS FOREIGN TRADE OF CHINA'S HIGH-TECH INDUSTRIES AND CARBON EMISSIONS}

\section{A. Unit root test}

We can verify the stability of time series by the statistics, besides the graphical intuitive judgment, and statistical tests are more accurate and important than the graphical judgments
There are many methods of unit root test, and this paper mainly uses the ADF test.[5] The sample size is used is 20 in this paper, in order to avoid reducing the degree of freedom, the lagged items in the test equation are not suitable for too many. Thus, we select less lagged items in the paper. We calculate the correlation time series data of carbon emission and import and export based on the software Eviews6.0,. The test results were shown in table I 
TABLE I.

STABILITY TEST RESULTS OF RESIDUAL SEQUENCE

\begin{tabular}{|c|c|c|c|c|c|c|c|}
\hline \multirow[b]{2}{*}{ List } & \multicolumn{7}{|c|}{ Level } \\
\hline & $\begin{array}{l}\text { Inspection form } \\
(\mathrm{c}, \mathrm{t}, \mathrm{n})\end{array}$ & $\mathrm{ADF}$ & $\begin{array}{c}\text { 1\% The critical } \\
\text { value }\end{array}$ & $\begin{array}{l}5 \% \text { The critical } \\
\text { value }\end{array}$ & $\begin{array}{l}10 \% \text { The critical } \\
\text { value }\end{array}$ & $\begin{array}{l}\text { Concomitant } \\
\text { probability }\end{array}$ & Conclusion \\
\hline LNC & $(c, 0,2)$ & -0.078392 & -3.808546 & -3.020686 & -2.650413 & 0.9394 & unstable \\
\hline LNX & $(c, 0,2)$ & 0.022197 & -3.808546 & -3.020686 & -2.650413 & 0.9502 & unstable \\
\hline $\begin{array}{c}\Delta \\
\mathrm{LNC}\end{array}$ & $(c, 0,2)$ & -2.061116 & -3.831511 & -3.029970 & -2.655194 & 0.2608 & unstable \\
\hline $\begin{array}{c}\Delta \\
\text { LNX }\end{array}$ & $(c, 0,2)$ & -1.842711 & -3.831511 & -3.029970 & -2.655194 & 0.3500 & unstable \\
\hline $\begin{array}{c}\Delta^{2} \\
\text { LNC }\end{array}$ & $(c, 0,2)$ & -3.242521 & -3.857386 & -3.040391 & -2.660551 & 0.0340 & stable \\
\hline $\begin{array}{c}\Delta^{2} \\
\text { LNX }\end{array}$ & $(c, 0,2)$ & -3.034820 & -3.857386 & -3.040391 & -2.660551 & 0.0505 & stable \\
\hline
\end{tabular}

After conducting the unit root test for the carbon emissions and foreign trade volume of China's high-tech industry, it can be seen that time series can become stationary when they are given the two order difference, so the original sequence of the two are single order sequences of order 2, which indicates that there may be long-term stable relations between the two and then we need the Co-integration test to analyze.

\section{B. Co-integration test}

The foreign trade volume of China's high-tech industry and the carbon emissions are second order single, so we can conduct the Co-integration test.[6] In this paper, the Engle-Granger two-step method is used to do the co-integration test. The first step is to estimate the long-term equilibrium equation of China's carbon emissions and the import and export volume of high-tech industries by OLS method:

$$
L N C_{t}=0.359813 L N X_{t}+8.487564 \text {, }
$$

And then we can find the corresponding residuals according to the equation:

$$
e_{t}=L N C_{t}-0.359813 L N X_{t}-8.487564
$$

The second step is to test the stability of the residual sequence $e_{t}$. If $e_{t}$ is stable, the variable $Y_{t}$ has a co-integration relationship with $X_{t}$. Otherwise, there is no co-integration relationship between them. The stability test results of residual sequences are shown in table II.

The table II shows the statistical value of ADF of the residual sequence is less than the critical value of the significance level of $10 \%$ through the stability test of the residual sequence $e_{t}$, and the original assumption of the unit root is rejected, that is, the residual sequence is a stationary sequence. This shows that there is a co-integration relationship between LNC and LNX. In other words, there is a long-term stable equilibrium between China's carbon emissions and the total import and export trade of high-tech industries within the sample range.

\begin{tabular}{|c|c|c|c|c|c|c|c|}
\hline \multirow{2}{*}{ List } & \multicolumn{7}{|c|}{ Level } \\
\hline & $\begin{array}{c}\text { Inspection form } \\
(\mathrm{c}, \mathrm{t}, \mathrm{n})\end{array}$ & $\mathrm{ADF}$ & $\begin{array}{c}\text { 1\% The critical } \\
\text { value }\end{array}$ & $\begin{array}{c}5 \% \text { The critical } \\
\text { value }\end{array}$ & $\begin{array}{l}\text { 10\% The critical } \\
\text { value }\end{array}$ & $\begin{array}{c}\text { Concomitant } \\
\text { probability }\end{array}$ & conclusion \\
\hline Residual & $(0,0,3)$ & -1.788149 & -2.692358 & -1.960171 & -1.607051 & 0.0707 & stable \\
\hline
\end{tabular}

TABLE II. STABILITY TEST RESULTS OF RESIDUAL SEQUENCE

The specific relation is the equation: LNC $=0.359813 \mathrm{LNX}+8.487564$. That is to say, China's carbon emissions increases by $0.3598 \%$ as the import and export volume of China's high-tech industries increases by $1 \%$. This shows that the foreign trade of China's high-tech industries has a certain impact on carbon emissions.

\section{Error correction}

The co-integration test results show that the carbon emissions and foreign trade of high technology industry in our country have long-term equilibrium relationship, but the long-term stable equilibrium relationship is continuously adjusted to maintain in the short-term dynamic process. [7]In order to make up for the defects that co-integration test can only analyze the long-term equilibrium relationship among indicators, error correction model is established to analyze the dynamic relationship between carbon emissions and foreign trade of high technology industries in our country. The paper lead to an error correction model after first order difference by Eviews6.0:

$$
\begin{array}{rl}
\Delta L N C_{t}=0 & 106140 \Delta L N X_{t}+0.409452 \Delta L N C_{t-1} \\
& +0.015405 \Delta L N X_{t-1}-0.387025 \Delta e_{t-1} \\
& +0.011760
\end{array}
$$

Among them, the correlation coefficient $\mathrm{R}=0.758$, statistic $\mathrm{F}=5.4$, and the corresponding probability statistic $\mathrm{F}$ value $\mathrm{P}=0.006$ is less than the significance level $\propto=0.05$, which shows that foreign trade of high technology industry in our country and carbon emissions have some short-term dynamic changes relationships.

And the regression results show that the short-term change of China's high technology industry's foreign trade growth has 
a positive impact on carbon emissions, and foreign trade increases $1 \%$ in this period, the carbon emission will increase by $0.106 \%$. The last period of foreign trade increased $1 \%$, the carbon emissions will increase by $0.015 \%$ in this period. Carbon emissions from the previous period also have a positive impact on carbon emissions. Carbon emissions increased $1 \%$ in last period, carbon emissions will increase by $0.409 \%$ this period. In addition, it can be seen from the equation that the error correction coefficient is -0.387 , which indicates that the annual carbon emissions and the long-term equilibrium value of deviation of $38.7 \%$ has been fixed when lagged one period, and it promoted the long-term equilibrium relationship between carbon emissions and foreign trade of high technology industries.

\section{CONCLUSION}

As described above, it can be seen that there is a high degree of long-term positive correlation and significant short-term dynamic correlations between the import and export volume of China's foreign trade and the carbon emissions. In addition, from the long term, the development of foreign trade of high-tech industry will continue to influence the environmental problems of our country and carbon emissions still face long-term severe challenges. And this also has a certain relation with our country's extensive economic growth and unreasonable product structure of foreign trade

\section{REFERENCES}

[1] Bin Shui and Robert C.Harriss. The role of $\mathrm{CO} 2$ embodiment in USChina trade[J]. Energy Policy, 2006, 34(18): 4063-4068.

[2] Boqiang Lin and Chuanwang Sun. Evaluating carbon dioxide emissions in international trade of China[J]. Energy Policy, 2010, 38(1): 613-621.

[3] Porter, A. L., Newman, N. C., Roessner, J. D., Johnson, D. M. and Jin, X. Y. International High Tech Competitiveness: Does China Rank Number[J]. Technology Analysis \& Strategic Management, 2009, 21 (2): 173-193.

[4] Jun Zhang. Study on the impact of export trade on China's carbon emission-. (In Chinese)

[5] Analysis of China's carbon dioxide emission growth factor - based on SDA decomposition technology .(In Chinese)

[6] Zihua Wei. Empirical research on the relationship between China's carbon emissions and economic growth-. (In Chinese)

[7] Pei Zhang. Study on the impact of carbon tariff on export competitiveness of China's textile and garment products.(In Chinese) 